with the slates in the beds of the Mekong and Salween further north (i.e. in the north-east) and the oldest rocks in this region.

It will be readily recognized how complicated is the geology of this region and how difficult it will be to unravel, not only on account of the vast extent of country involved and the physical difficulties of travel, but also owing to the alterations and displacements of the strata consequent on the great irruptions of granite, which is found from the river-beds, 6,000 feet above sea-level, to the crests of the Mekong-Salween divide at 18,000 feet, and to the fact that the Burmese hinterland is covered with impenetrable jungle.

To sum up. Everything in the arrangement of the rocks throughout this region so far as $I$ am acquainted with it, points to a synclinal structure, or more accurately fan structure, between the Brahmapootra and the Yangtze, induced by a pressure acting from west to east as the final phase of crust movement, which breached a continuous Sino-Himalayan axis, the result of a previous crust movement from south to north. The present hydrography of the region is due to a fusion of two sets of rivers which have become involved since the second phase of crust movement; the peculiar loops into which some of the rivers have been thrown must be ascribed partly to the buckling and twisting of vertical strata consequent on pressure acting at right angles to the dip, whereby rivers following the strike of the rocks have been thrown out of their course. Finally, there has been a rift formation in addition, due to a lateral tension strain, acting at right angles to the long axes of the synclines, or to a sagging of the anticlines with consequent rupture of the synclines. Complications have been introduced by the bursting through of enormous masses of granite, which have tossed aside and altered the sedimentary rocks. The whole of this region must once have been under water like the Hkamti plain, but in the east subsequent alteration has gone so far that there are no clays and sandstones left, and the further east one goes the greater is the metamorphism and crumpling of the rocks. Possibly the pressure which gave rise to these mountain ranges is still acting from the west, and the white mountains which lift up their heads so proudly will grow yet higher and grander; but the fires which blasted this corner of Asia are drawn, the great lakes are ilrained. Only the restless rivers still pour through the terrific breach in the Asiatic divide to the hot south, to be followed through the rent they had torn not less impetuously by the hordes of hardy northmen who, six centuries before Christ, orerran the plains of Indo-China.

\title{
NOTIOFS OF MFMOIES.
}

\section{Artesian Water in Manitoba." By J. B. Tybelel.}

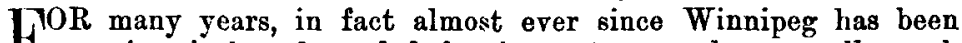
1 a city, it has depended for its water supply on wells sunk through the impervious layer of Boulder-clay which underlies the city, into a bed of porous limestone from which water rises in great abundance. From these wells the city has been able to obtain

'From the Canadian Engineer, vol. xxvi, No. 15, p. 574, April 9, 1914. 
a plentiful supply of water which, while containing a slight amount of mineral matter, is absolutely free from any hurtful bacteria, or from organic germs of any kind.

The porous limestone into which these wells are sunk, and from which the water rises, extends to the north and west beneath a layer of Boulder-clay, and rises to the surface in a number of places in the country between Lakes Winnipeg and Manitoba at elerations varying from about fifty to one hundred and fifty feet above the level of the prairie at Winnipeg. The rain falls on these bare rocky areas, as well as on the adjoining clay-covered country, but instead of flowing away in rills and streams, as it does on the clay-covered country, it at once sinks into the porous limestone and flows through this limestone southward and eastward until it finally reaches the surface either in the large springs north of Winnipeg or through the wells at the city of Winnipeg itself. The quantity that flows from these springs and wells is therefore largely limited to the amount of the rainfall on those portions of the surface where the porous limestone is uncovered. Where it is covered, as it is in many places, most of the water derived from the rain either stands in small lakes and evaporates from the surface, or drains off towards Lake Winnipeg or Lake Manitoba by the many streams which unwater the country.

The underlying porous limestone through which the water percolates on its way from the exposed areas north-west of Winnipeg to the wells in Winnipeg is a magnificent natural filter which is protected from contaminating influences throughout the populated parts of Manitoba by a thick covering of impervious Boulder-clay. No other city on the continent is provided by nature with such a filter, and no city could afford to duplicate it.

\section{REVIFWS.}

I.-Memoirs of the Geological Survey of England and Wales.

The Coals of Sodth Wales, with special heference to the Origin and Distribution of Anthractte. By Adbuey Strahan, M.A., Sc.D., LL.D., F.R.S., and W. Polcand, M.A., D.Sc., F.I.C., assisted by E. G. RadLey. 2nd ed. 8vo; pp. 78, with 10 plates. 1915. Price 1s. 6d. E. Stanford, Long Acre, or any agent for the sale of Ordnance Survey Maps.

WITH A MAP, reproduced from Plate IV by permission of the Controller of H.M. Stationery Office.)

CIOR a long series of years the energies of those geologists who are 1 also chemists seem to have been so concentrated upon questions of crystallization and the differentiation of igneous magmas that the corresponding and equally interesting problems of continuous variation in the composition of beds of sediment have remained outside the scope of their activities. To the nation sedimentary rocks are at least as important as igneous rocks. To our industries they are even of greater importance; and to those who have been called in to help in mobilizing home resources of raw materials and providing manufacturers with efficient substitutes for sedimentary materiuls till lately imported in bulk from abroad, the failure to take stock of this whole class of the nation's resources has seemed a neglect which 